\title{
レーザ照射によるチタンの表面窒化と耐摩耗性改善
}

\author{
山口富子 ${ }^{1}$ 米正 $\quad$ 裕 $^{2, *} \quad$ 西尾一政 ${ }^{2}$ \\ 1九州工業大学大学院工学研究院 \\ 九州工業大学大学院生命体工学研究科
}

J. Japan Inst. Metals, Vol. 75, No. 12 (2011), pp. 697-704

(C) 2011 The Japan Institute of Metals

\section{Surface Nitriding and Improvement of Wear Resistance of Titanium Using Laser Irradiation}

Tomiko Yamaguchi ${ }^{1}$, Yutaka Yonesho ${ }^{2, *}$ and Kazumasa Nishio ${ }^{2}$

${ }^{1}$ Graduate School of Engineering, Kyushu Institute of Technology, Kitakyushu 804-8550

${ }^{2}$ Graduate School of Life Science and Systems Engineering, Kyushu Institute of Technology, Kitakyushu 804-8550

\begin{abstract}
Pure titanium is a biocompatible material that is also useful in high-temperature environments, however, wear resistance of the pure titanium is weak. To improve the wear resistance of pure titanium, surface modification is performed using laser beam heating under various laser conditions. The modified surface layer produced by laser melting consists of titanium nitride (TiN), which improves the hardness and the wear resistance. However, the surface of this modified layer is not flat.

In this study, the laser irradiation was performed in a controlled atmosphere and the effects of the atmosphere on the microstructure, hardness, and wear resistance of the irradiated region were investigated. As the pure titanium surface was heated by laser irradiation, a TiN film was formed on its surface without the introduction of cracks. A lamellar structure was also observed under the TiN film. The maximum TiN thickness obtained without cracking or peeling of the base metal was approximately 13 $\mu \mathrm{m}$. In comparison with the base metal, the hardness and wear resistance of the TiN film were approximately 8 and 22 times higher, respectively.
\end{abstract}

(Received June 13, 2011; Accepted September 7, 2011)

Keywords: laser irradiation, titanium, TiN film, wear resistance

\section{1. 緒言}

人工股関節や人工歯根等の硬組織代替材料としては, 金属 系生体材料が主流であり, 主にステンレス鋼, $\mathrm{Co}-\mathrm{Cr}$ 系合 金, チタンが代表的である.これらの中で最も生体親和性に 優れるチタンは硬組織代替材料としての利用が注目されてい る. 生体への安全性が重要視されるようになり, 毒性のない 構成元素からなる生体用チタン合金が登場するようになって きている11). 一方, 生体内にインプラントされた状態で, 人 工股関節等の摺動部においては接触あるいは摩擦することに より摩耗が生じ, 表面の不動態皮膜の破損抢よび剥離や摩耗 粉の人体への影響が問題となる ${ }^{2)}$.

そこで, 摩耗粉発生の抑制という観点から, チタン材料の 耐摩耗性の向上を目的として, チタンに対するレーザビーム 加熱によりチタンの表面改質について検討した。これまで に, レーザ移動速度, シールドガスの種類およびシールドガ ス流量を変化させてレーザ照射を行い, 溶融部のミクロ組 織, 硬さおよび耐摩耗性について調査した ${ }^{3,4)}$. その結果, チタン板のレーザ表面改質層において, 溶融部内部は, 板幅 方向拈よび板厚方向ともに, ほぼ一定の硬さを有し, 窒素

*九州工業大学大学院生, 現在 : 新日本製鐵秼 (Graduate Student, Kyushu Institute of Technology, Present address: Nippon Steel Corporation)
シールドガスの使用によって, 約 $1040 \mathrm{HV}$ の表面改質層が 得られた. また, 比摩耗量は母材の約 $20 \sim 30 \%$ となり, 耐 摩耗性の大きな改善も認められた。これはレーザ溶融部内部 の全体に渡って, TiNの初晶デンドライトと $\alpha \mathrm{Ti} と \mathrm{TiN} の$ 共晶から成る層の形成に起因することを明らかにした ${ }^{4)}$.し かしながら, レーザ照射後, 照射表面には白色の酸化皮膜の 形成や割れの発生のため, 表面研削を行う必要があった.

一方，チタン表面の窒化には，ガス窒化処理 ${ }^{5)}$, PVD 法6) 等があるが, これらの方法では, 表面改質層の成長・形成に 長時間を要し, また特定の部位の久処理するためには, マス クをかけるなどの工数が増える.

本研究では, 急速加熱・急速冷却が可能なレーザ加熱法を 利用し, レーザ照射雾囲気を完全に制御して酸化を防ぐとと もに, 表面が溶融しないような条件でレーザ照射を行い, レーザ照射部の組織, 硬さおよび耐摩耗性に及ぼす雾囲気お よびレーザ照射回数の影響について検討した.

\section{2. 供試材および実験方法}

供試材は, 板厚 $t=2 \mathrm{~mm}$ の工業用純チタン $\mathrm{TP} 340 \mathrm{C}(2$ 種) および板厚 $t=7 \mathrm{~mm}$ の $\mathrm{TP} 270 \mathrm{H}(1$ 種 $)$ である.これらの 化学組成を Table 1 に示す. $t=2 \mathrm{~mm}$ の TP340C は, 板長 $120 \mathrm{~mm}$ および板幅 $60 \mathrm{~mm}$ の寸法に加工し, 一枚の板に十 分距離を離した二か所の位置に線状にレーザ照射を行った. 
Table 1 Chemical compositions of pure titaniums used.

(mass $\%)$

\begin{tabular}{ccccccc}
\hline & $\mathrm{N}$ & $\mathrm{H}$ & $\mathrm{Fe}$ & $\mathrm{O}$ & $\mathrm{Al}$ & $\mathrm{Ti}$ \\
\hline TP340C & 0.0004 & $<0.0013$ & 0.06 & 0.11 & - & Bal. \\
\hline TP270H & 0.0002 & - & 0.048 & 0.075 & $<0.01$ & Bal. \\
\hline
\end{tabular}

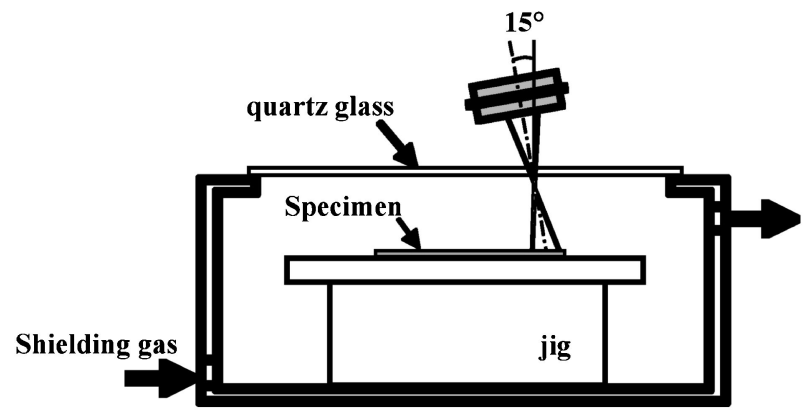

Fig. 1 Schematic illustration of laser irradiation.

この場合，レーザ照射後に若干の変形が生じた。摩耗試験用 の試料は平行度が要求されるため, 板厚の厚い $t=7 \mathrm{~mm}$ の $\mathrm{TP} 270 \mathrm{H}$ を用いた. $\mathrm{TP} 270 \mathrm{H}$ は $40 \mathrm{~mm} \times 40 \mathrm{~mm}$ の正方形に 加工し， $\phi 25 \mathrm{~mm}$ の円状にレーザ照射を行った。なお，使用 材料は入手の容易さを優先的に考えた。レーザ照射に先だ ち, 試験片表面はステンレス製ワイヤーブラシ $(\phi 0.3 \mathrm{~mm})$ を 用いて研磨後，アセトン洗浄して酸化皮膜を除去した.

Fig. 1 に示すように試験片は幅 $300 \mathrm{~mm}$ ，長さ $400 \mathrm{~mm}$ お よび高さ $100 \mathrm{~mm}$ のアクリル製の箱(以降Box とする)内に 設置後, 密閉した. その後, シールドガスを流量 $20 \mathrm{~L} / \mathrm{min}$ で 2 分間 Box 中に貯留させ, シールドガスを流しながら蓋 の空に固定した石英ガラスの上部よりレーザ照射した．

レーザ照射は YAG レーザ加工機(最大出力 : $2 \mathrm{~kW}$ )を用 いて，レーザビーム波形を連続波，レーザ出力 $P$ を 1.5 $\mathrm{kW}, レ ー サ ゙$ 移動速度 $v$ を $500 \mathrm{~mm} / \mathrm{min}$, 焦点外し距離 $F_{\mathrm{d}}$ を $35 \mathrm{~mm}$ の条件で，レーザ照射角度を $15^{\circ}$ 傾斜させて後退 法で行った。この条件におけるレーザ照射の幅は約 $6 \mathrm{~mm}$ で あった、シールドガスには， $\mathrm{Ar}=100 \%, \mathrm{Ar}: \mathrm{N}_{2}=90: 10$, $70: 30,50: 50,30: 70$ ，および $\mathrm{N}_{2}=100 \%$ 窒素ガス割合 が異なる 6 種類を使用した. Ar : $\mathrm{N}_{2}$ の混合ガスは市販品を 使用した． $t=2 \mathrm{~mm}$ の試験板の場合には，同じ場所に 1,2 , 4 および 6 回の線状レーザ照射を行った。 1 回目のレーザ照 射後, 次のレーザ照射までシールドガスを $10 \mathrm{~L} / \mathrm{min}$ で 2 分 間流しながら試験板の冷却を行った。 $t=7 \mathrm{~mm}$ の試験板の 場合には，1回のレーザ照射後，冷却するような繰返しでは $t=2 \mathrm{~mm}$ の試験板と同等の皮膜厚さを得ることが困難であ ったため，試験板を冷却せずに連続 5 回のレーザ照射を行 った後, シールドガスを $10 \mathrm{~L} / \mathrm{min}$ 流して試験板を 2 分間冷 却し，その後連続 5 回のレーザ照射を行った。連続レーザ 照射ではレーザ照射回数の合計が 5 回，20 および 40 回まで 同じ場所へ円形状に照射した。なた，裏面側から $\phi 0.5 \mathrm{~mm}$ の穴を表面から約 $0.5 \mathrm{~mm}$ の位置まで加工し，穴の底面に $\mathrm{R}$ 熱電対をパーカッション溶接した。そして，試験片の表面に レーザ照射を行い，その際の温度を測定した。
レーザ照射後，断面のマクロ組織およびミクロ組織をそれ ぞれ実体顕微鏡および光学顕微鏡により観察した。観察面は 鏡面研磨後, クロール液 (弗酸 : 硝酸 : 蒸留水 $=2: 5: 100$ ) 中で約 45 秒間腐食した.レーザ照射によって表面に生成さ れた物質は $\mathrm{X}$ 線回折 $(\mathrm{CuK} \alpha$ を使用)により同定した。レー ザ照射部抢よびその近傍の硬さは，マイクロビカース硬さ試 験機 (MATSUZAWA SEIKI 製，負荷荷重 $1.96 \mathrm{~N}$ ，保持時 間 $30 \mathrm{~s}$ )を用いて測定した。ビッカース硬さ試験を行った 後, 試料表面に最も近いビッカース圧痕の位置までは超微小 押込久硬さ試験機ナノ・インデンテーション・テスター(珠) エリオニックス製，ENT-1100a 試験荷重 0.98 N) を使用し て硬さを測定した。摩耗試験は, Ball-on-Disc Type の回転 型摩耗試験機 (JIS T 0303 に準拠，侏レスカ製 FPR-2000) を使用し，摩耗相手材に $\phi 5.0 \mathrm{~mm}$ のジルコニアボールを用 いて, 摩耗荷重 $4.9 \mathrm{~N}$, 摩耗速度 $20 \mathrm{~mm} / \mathrm{s}$ および摩耗時間 4, 16, 36, 60 および $90 \mathrm{~h}$ の条件で行った。なお，摩耗試験 中は潤滑液として純水を用い, 試験片および潤滑液の温度を $37^{\circ} \mathrm{C}$ と一定とした。潤滑液は約 20 時間毎に補充を行った。 試験前後の試験板の秤量に際し, 試験板の洗浄は, 蒸留水中 で約 30 分間超音波洗浄を行った後，エタノール中で約 10 分間の超音波洗浄を行った. その後, 乾熱滅菌機を用いて $45^{\circ} \mathrm{C}$ で 2 時間乾燥させ，デシケータ内で室温まで冷却した 後, 試験板の秤量を行った.

\section{3. 実験結果および考察}

\section{$3.1 t=2 \mathrm{~mm}$ の試験板上に線状レーザ照射を行った場合}

\subsection{1 レーザ照射部の温度変化}

レーザ移動速度を $500 \mathrm{~mm} / \mathrm{min}$ ，焦点外し距離を $35 \mathrm{~mm}$ とし，シールドガス 6 種類を使用し，試験板上に線状の レーザ照射した際の温度変化を測定した．Fig. 2 に温度変化 曲線を示す，最高到達温度は $\mathrm{Ar}=100 \%$ の場合に約 $1100^{\circ} \mathrm{C}$ を示し，シールドガス中の窒素割合が増加すると約 $1350^{\circ} \mathrm{C}$ まで加熱されるが， $\mathrm{N}_{2}=100 \%$ の場合には約 $1100^{\circ} \mathrm{C}$ に低下 した.

\subsection{2 レーザ照射部の外観およびミクロ組織}

Fig. 3 にシールドガスに $\mathrm{Ar}=100 \%, \mathrm{Ar}: \mathrm{N}_{2}=90: 10$, 30 : 70，および $\mathrm{N}_{2}=100 \%$ を使用し，6 回照射した場合の線 状レーザ照射表面の外観を示す． $\mathrm{Ar}=100 \%$ の場合のレーザ 照射部に白色の酸化皮膜は見られず，Box 内雾囲気は十分 に $\mathrm{Ar}$ 置換されている．窒素ーアルゴン混合ガスおよび $\mathrm{N}_{2}=$ 100\%を使用した場合では，すべてのレーザ照射部表面は黄 土色を呈し， $\mathrm{N}_{2}$ 量の増加またはレーザ照射回数 $N$ の増加に より黄土色は濃くなる傾向が見られた。また，照射回数の増 加によって試験片に変形が見られたが，レーザ照射部には亀 裂や割れは見られなかった。

Fig. 4 にシールドガスに Ar : 100\% および Ar : $\mathrm{N}_{2}=30$ : 70 を用いて，線状にレーザ照射を行った場合の照射部断面 のマクロ組織を示す，母材に比べてレーザ照射領域では結晶 粒の粗大化が見られ，以降結晶粒粗大化部と称する.

Fig. 5 にシールドガスに Ar：100\%抢よび Ar : $\mathrm{N}_{2}=30$ : 70 を用いて，線状にレーザ照射を行った場合の照射部断面 
のミクロ組織を示す． $\mathrm{Ar}=100 \%$ 用いた場合は照射表面お よび内部において大きな変化は見られない(Fig. 4 (a)).

$\mathrm{Ar}: \mathrm{N}_{2}=30$ ：70 を用いてレーザ照射した場合には，表面に 白いコントラストの層(皮膜) とその下に針状組織が認められ る (Fig. 4(b) および (c)). 照射回数 $N$ を 1 および 6 とレー ザ照射回数を増加させると皮膜の厚さおよび針状組織の厚さ は増大している。

Fig. 6 に $\mathrm{Ar}: \mathrm{N}_{2}=30: 70$ を用い，照射回数 6 回の場合の 試料表面に対する X 線回折の結果を示す。 $\alpha \mathrm{Ti}$ の他に $\mathrm{TiN}_{0.3}$ および $\mathrm{TiN}$ のピークが認められる．針状の組織は窒 素含有量の多い相と少ない相のラメラー組織からなり, $\mathrm{TiN}_{0.3}$ は針状の組織より検出されるものと考えられる3). 皮 膜は TiNであると同定される。 また，レーザ照射回数を増 加させると表面の凹凸が激しくなっていた。これは固溶した 窒素の影響抢よび急冷により $\alpha^{\prime}$ マルテンサイト組織が形成 されたことに起因すると考えられる．

Fig. 7 に TiN 皮膜厚さ $X_{\mathrm{TiN}}$ およびラメラー組織の厚さ $X_{\mathrm{lam} .}$.に及ぼす窒素ガス割合の影響を示す。ミクロ組織は 4 視野観察し，1 視野において 4 箇所，計 16 箇所の厚さを測 定しその平均值で評価した， TiN 皮膜厚さおよびラメラー 組織の厚さは, 照射回数が増加するにつれて増大している. また， TiN 皮膜厚さ抢よびラメラー組織の厚さは，窒素ガ 又割合によって変化し, $\mathrm{Ar}: \mathrm{N}_{2}=30: 70,6$ 回照射の場合に それぞれ最大 $13 \mu \mathrm{m}$ 抢よび $71 \mu \mathrm{m}$ の厚さが得られ, 窒素ガ

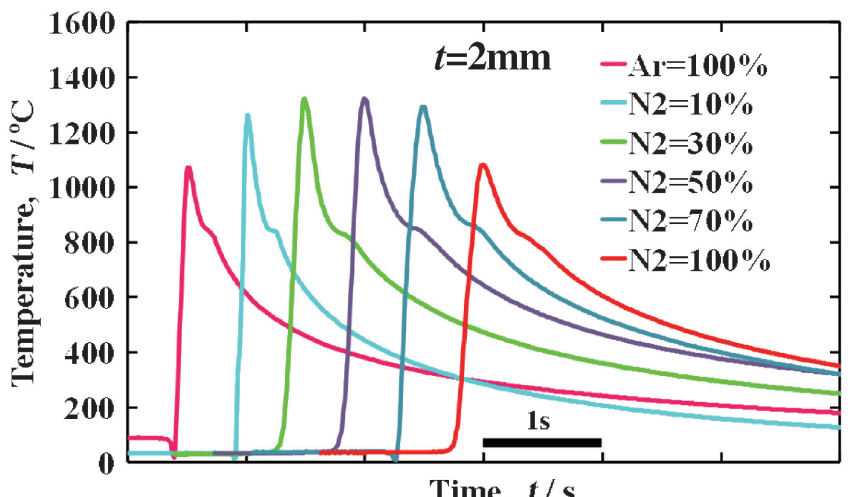

Fig. 2 Temperature changes of titanium plate during laser irradiation in laser power of $1500 \mathrm{~W}$, laser traveling speed of 500 $\mathrm{mm} / \mathrm{min}$ and defocus distance of $35 \mathrm{~mm}(t=2)$.
ス割合が $65 \%$ 前後で最も厚くなる傾向が見られる。これは， Fig. 2 に示したように， $\mathrm{N}_{2}=100 \%$ を使用した場合の試料の 表面温度は他のシールドガスを使用した場合に比べて $300^{\circ} \mathrm{C}$ 程低下していたため, 皮膜厚さの成長が抑制されたものと考 えられる。

\subsection{3 レーザ照射部の硬さ分布}

レーザ照射部に形成した $\mathrm{TiN}$ 皮膜およびラメラー組織の ナノインデンテーション硬さを測定した．結晶粒粗大化部の マイクロビッカース硬さは母材とほぼ同等の約 $150 \mathrm{HV}$ であ った.

Fig. 8 に Ar: $\mathrm{N}_{2}=30: 70, N=6$ の場合のナノインデン テーション硬さ分布および硬さ測定時のミクロ組織を示す.

$\mathrm{TiN}$ 被膜, ラメラー組織および結晶粒粗大化部の 3 つの組 織と硬さ分布は，組織変化に対応した硬さ分布が得られたこ とがわかる。 また，表面付近の(1)の部分の硬さは $39 \mathrm{GPa}$ と 非常に大きな值を示し，母材 $(5 \mathrm{GPa})$ の約 8 倍である. ラメ ラー組織の硬さは皮膜付近で最も高く約 $10 \mathrm{GPa}$ であるのに

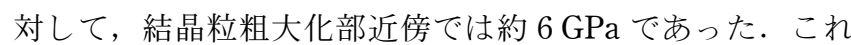
は，表面近傍では温度が非常に高く窒素の拡散は容易である のに対して，試料内部では温度が低く冷却速度が大きいため

(a)

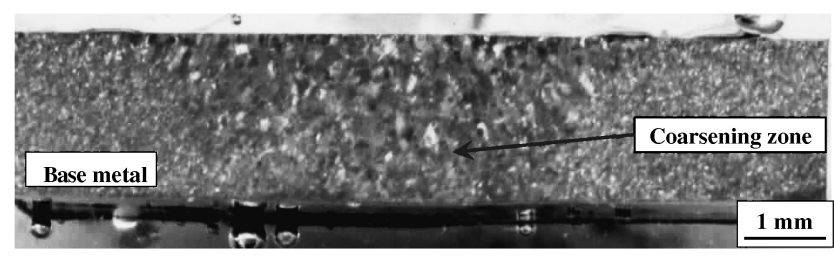

(b)

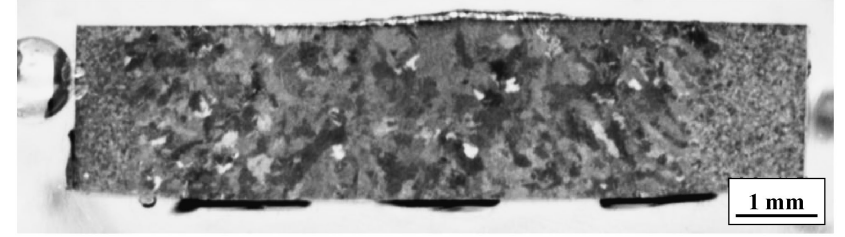

Fig. 4 Macrostructures after laser irradiation in an atmosphere of (a) $\mathrm{Ar}=100 \%$, 1 time and (b) $\mathrm{Ar}: \mathrm{N}_{2}=30: 70$, 6 times $(t=2)$.
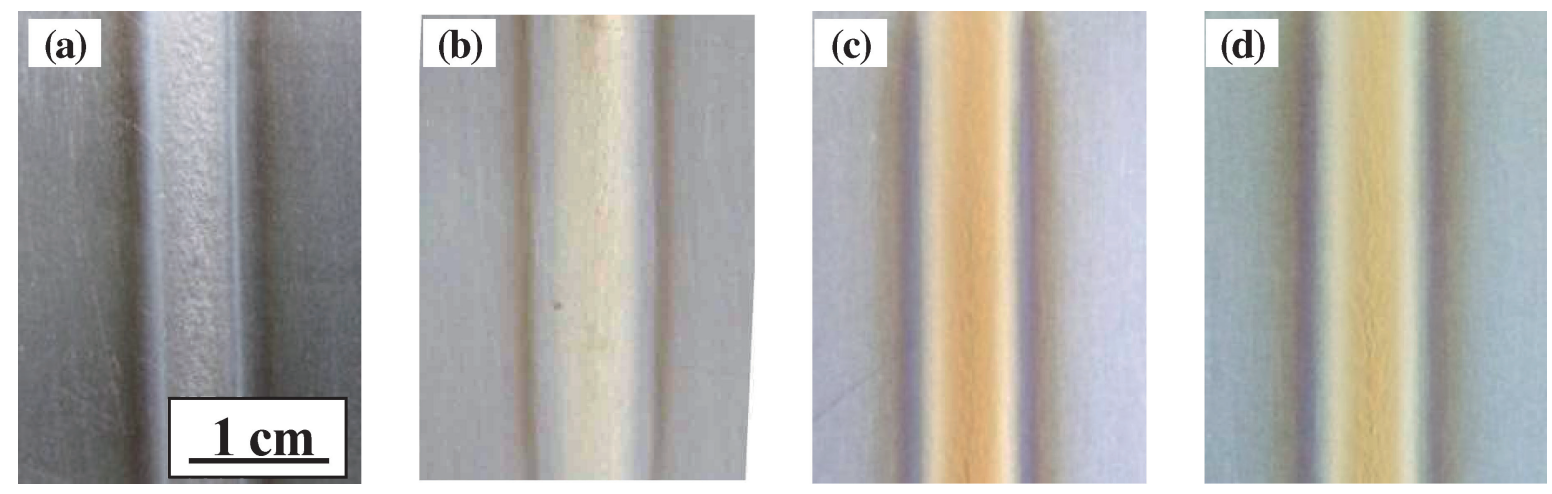

Fig. 3 Macrostructures after 6 times of laser irradiation in an atmosphere of (a) $\mathrm{Ar}=100 \%$, (b) $\mathrm{Ar}: \mathrm{N}_{2}=90: 10$, (c) $\mathrm{Ar}: \mathrm{N}_{2}=$ $30: 70$ and (d) $\mathrm{N}_{2}=100 \%(t=2, N=6)$. 


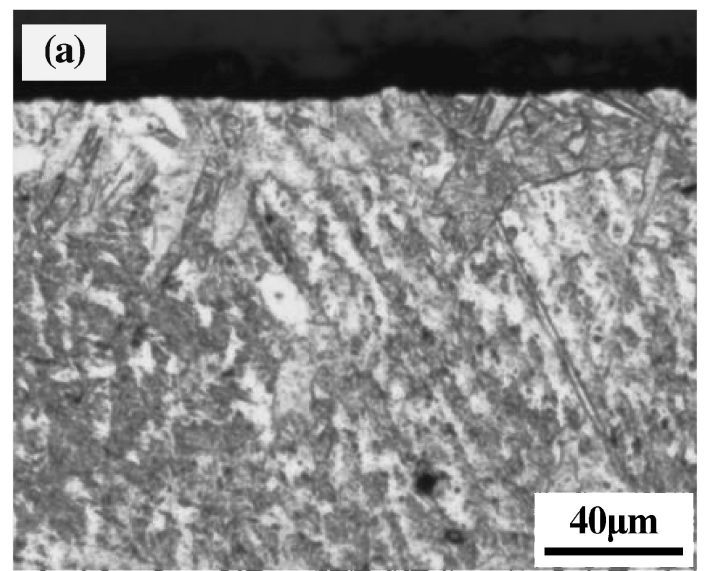

(a) $\mathrm{Ar}=100 \%, \mathrm{~N}=1$

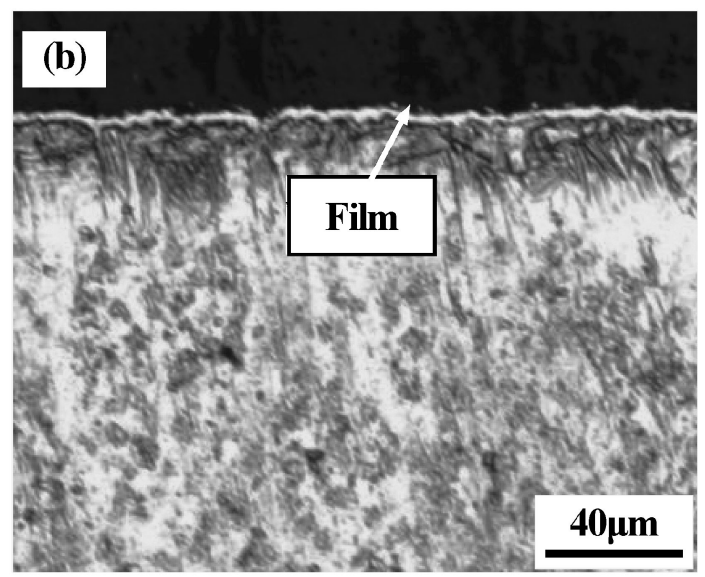

(b) Ar: $22=30: 70, \mathrm{~N}=1$

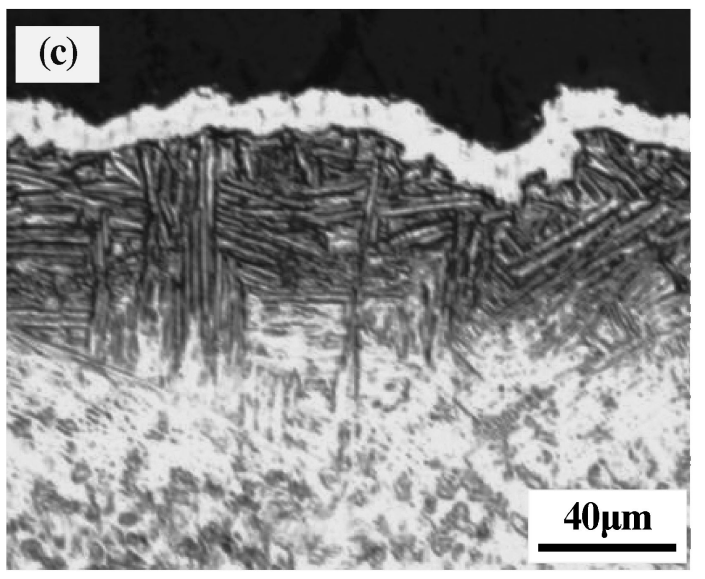

(c) $\mathrm{Ar}: \mathrm{N} 2=30: 70, \mathrm{~N}=6$

Fig. 5 Microstructures of cross section specimen after laser irradiation in an atmosphere of (a) $\mathrm{Ar}=100 \%, N=1$, (b) $\mathrm{Ar}$ : $\mathrm{N}_{2}=30: 70, N=1$ and (c) Ar $: \mathrm{N}_{2}=30: 70, N=6(t=2)$.

窒素の固溶量が減少したことによると思われる. (2) 打よび(3) は, ラメラー組織部の中の色の濃い部分であるが, 硬さが低 下している．この色の濃い部分はラメラー組織の中でも窒素 量が低い部分であると思われ，そのため，ラメラ一組織の硬 さ分布にばらつきが生じたと思われる.

Fig. 9 に試料表面近傍のナノインデンテーション硬さに及 ぼすレーザ照射回数の影響を示す． $\mathrm{Ar}=100 \%$ の場合には，

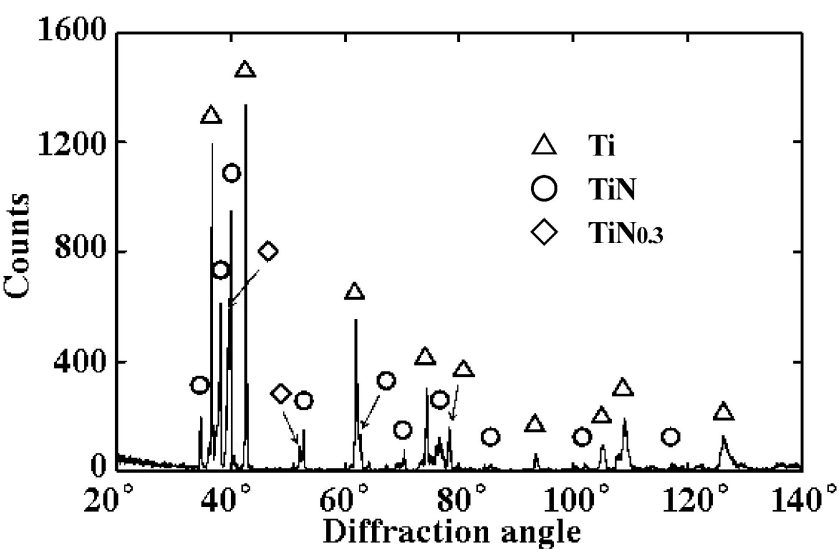

Fig. 6 XRDP of cross section specimen after laser irradiation in an atmosphere of $\mathrm{Ar}: \mathrm{N}_{2}=30: 70, N=6(t=2)$.
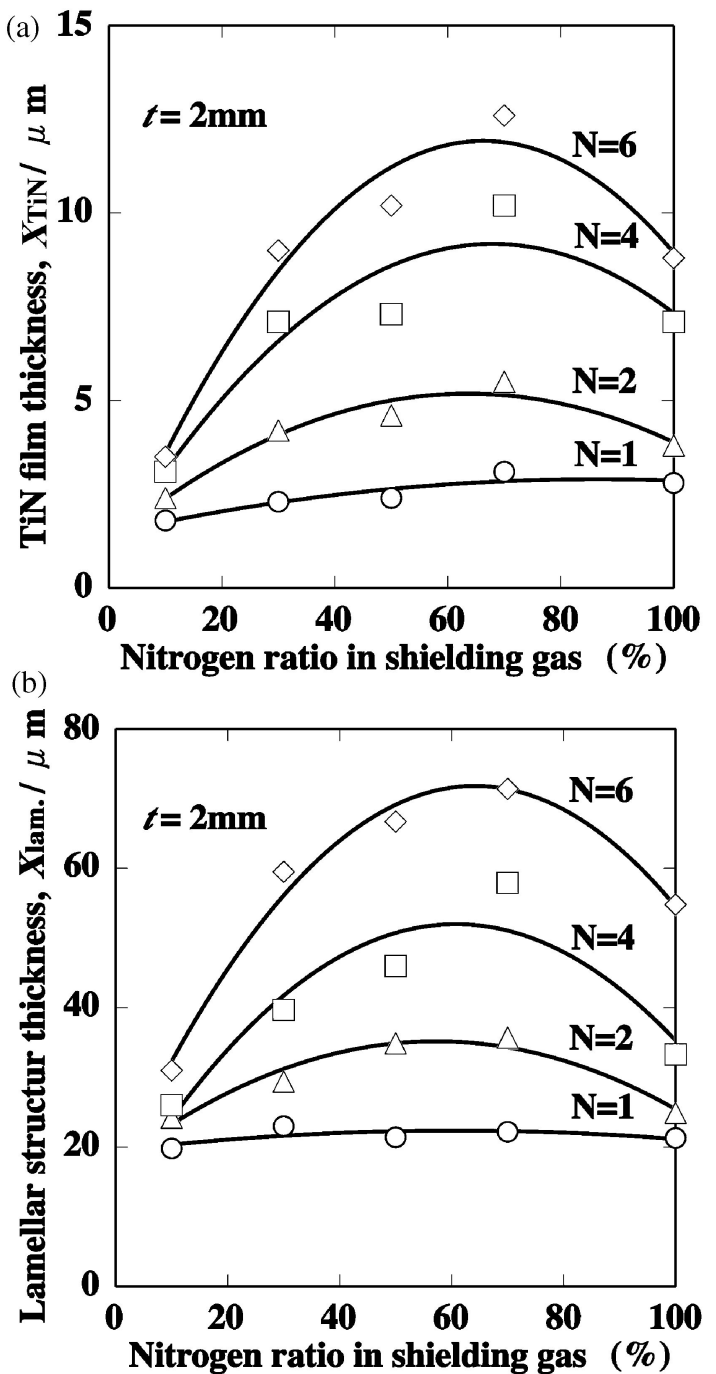

Fig. 7 Effects of nitrogen ratio in shielding gas on (a) TiN film thickness and (b) lamellar structure thickness $(t=2)$.

硬さに変化が見られず約 $5 \mathrm{GPa}$ である. シールドガス中の $\mathrm{N}_{2}=10 \%$ の場合, 照射回数 1 回で $10 \mathrm{GPa}, 2$ 回以降で 20 GPa 前後に硬化した. $\mathrm{N}_{2}=30,50$ および $70 \%$ の場合では, 照射回数 1 回で $20 \mathrm{GPa}$ に硬化し, 照射回数の増加とともに 硬さは増加し $40 \mathrm{GPa}$ 前後の值が得られている. $\mathrm{N}_{2}=100 \%$ 


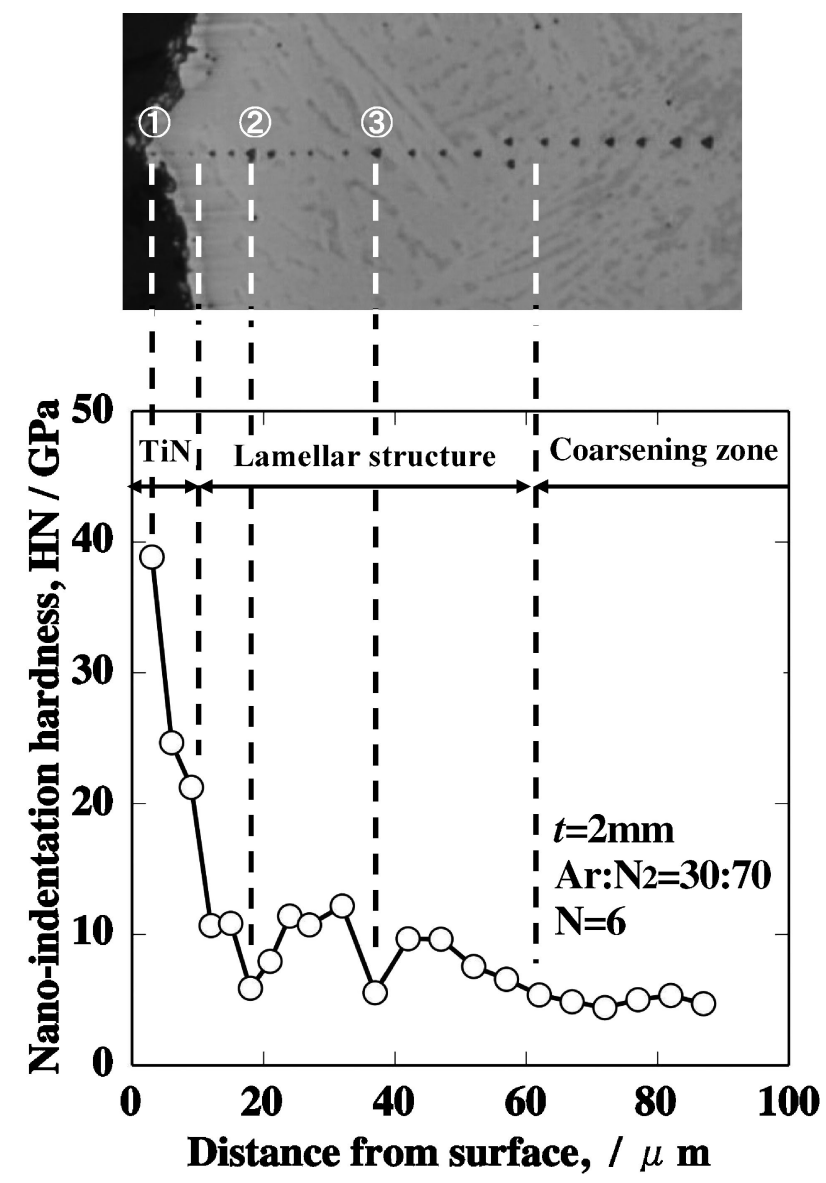

Fig. 8 Nano-indentation hardness of laser surface modification $(t=2)$.

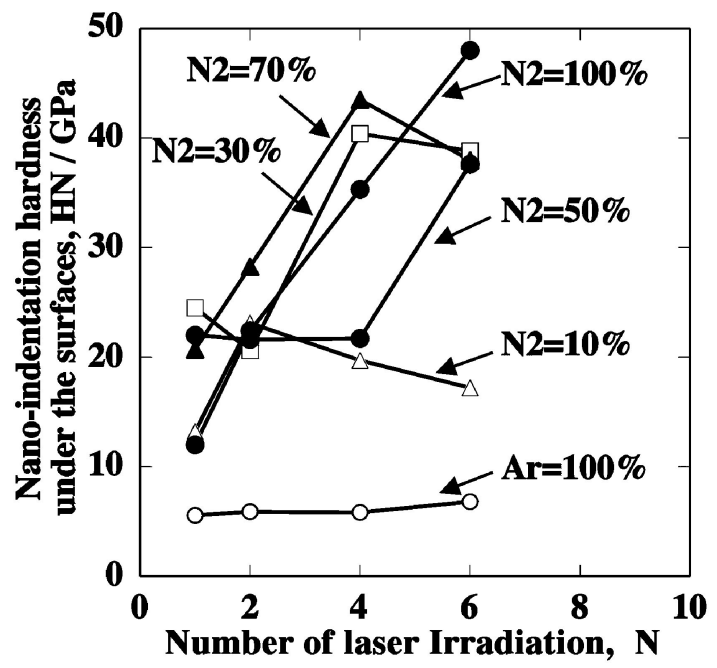

Fig. 9 Effects of number of laser irradiation on nano-indentation hardness under the modification surfaces $(t=2)$.

では照射回数の増加とともに硬さは $10 \mathrm{GPa}$ から約 $50 \mathrm{GPa}$ まで増加した。一方, 平均ラメラー組織の硬さ打よび結晶粒 粗大化部の硬さに変化は見られなかった.

$3.2 t=7 \mathrm{~mm}$ の試験板上に円形状のレーザ照射を行った場 合

$t=2 \mathrm{~mm}$ に扔いて $\mathrm{TiN}$ 皮膜が最も厚く成長していたシー

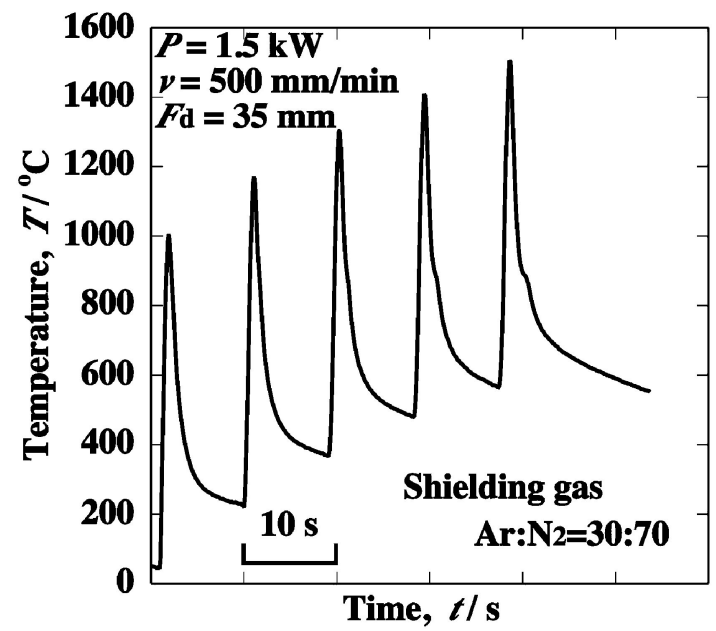

Fig. 10 Temperature change of titanium plate during cyclic laser irradiation in laser power of $1500 \mathrm{~W}$, laser traveling speed of $500 \mathrm{~mm} / \mathrm{min}$ and defocus distance of $35 \mathrm{~mm}(t=7)$.

ルドガス $\mathrm{Ar}: \mathrm{N}_{2}=30: 70$ を用いて,$t=7 \mathrm{~mm}$ のチタン板 に対して摩耗試験用に円形状のレーザ照射を行った。

\subsection{1 レーザ照射部の外観およびミクロ組織}

$t=7 \mathrm{~mm}$ の試験片において, 同じ場所へ円形状にレーザ 照射回数の合計が 5,20 おょよ゙ 40 回まで照射した. Fig. 10 にシールドガスに Ar: $\mathrm{N}_{2}=30: 70$ を使用した際の温度変化 曲線を示す、レーザ照射部表面は室温まで冷却されることな く, 1 回のプログラムで 5 回の連続したレーザ照射を行った ため高温での保持時間が長くなり, 窒素の拡散量が増大した と考えられる。

Fig. 11 にシールドガスとして Ar : $\mathrm{N}_{2}=30 ： 70$ を使用 し，レーザ照射回数 $N$ が 5,20 抢よび 40 まで円形状に照射 した場合のレーザ照射表面の外観を示す.レーザ照射回数 $N$ の増加によりレーザ照射部表面は肌色から黄土色に変化 するが，色むら，試験片の変形，レーザ照射部の亀裂や割れ は見られなかった。

Fig. 12 に $\mathrm{Ar}: \mathrm{N}_{2}=30: 70$ を用いてレーザ照射回数 $N$ を 5,20 抢よび 40 と変化させて円形状に連続でレーザ照射し た場合のレーザ照射部の断面ミクロ組織を示す. 照射回数 $N$ が増加するに従って, TiN 皮膜厚さ抢よびラメラー組織 厚さが厚くなっている.

Fig. 13 に TiN 皮膜厚さ㧍よびラメラー組織厚さに及ぼす レーザ照射回数の影響を示す. TiN 皮膜厚さ打よびラメ ラ一組織厚さは, 照射回数が増加するにつれてほぼ直線的に 増大し，照射回数 $N$ が 40 においてそれぞれ 14 および 53 $\mu \mathrm{m}$ であった。

\subsection{2 摩耗試験による耐摩耗性の検討}

$\mathrm{TiN}$ 皮膜厚さが最も厚い条件であるシールドガスに $\mathrm{Ar}$ ： $\mathrm{N}_{2}=30: 70$ を使用して, 連続レーザ照射によって 40 回照 射した試験板に対して摩耗時間を $4,16,36,60$ および $90 \mathrm{~h}$ として摩耗試験を行った。 また, 比較材として母材抢よび シールドガスに $\mathrm{Ar}=100 \%$ を使用して，連続レーザ照射に よって 40 回照射した試験片に対しても同様に摩耗試験を行 った.

Fig. 14 に母材，シールドガスに $\mathrm{Ar}=100 \%$ 抢よび $\mathrm{Ar}$ : 

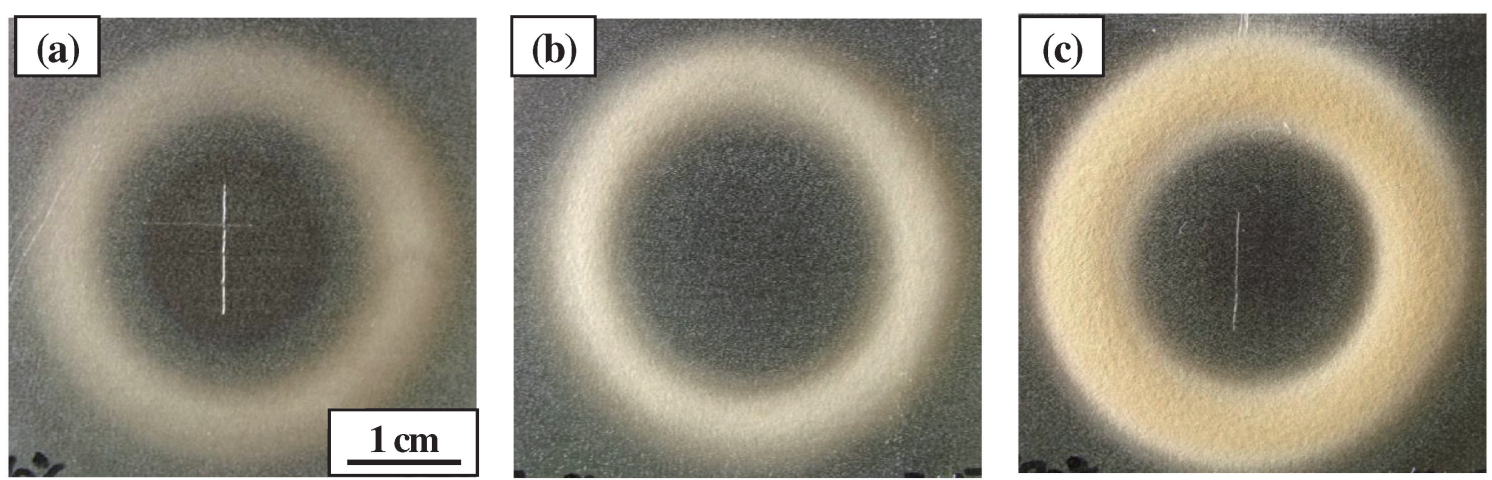

Fig. 11 Macrostructures after laser irradiation in an atmosphere of $\mathrm{Ar}: \mathrm{N}_{2}=30: 70(t=7)$ (a) $N=5$, (b) $N=20$ and (c) $N=40$.
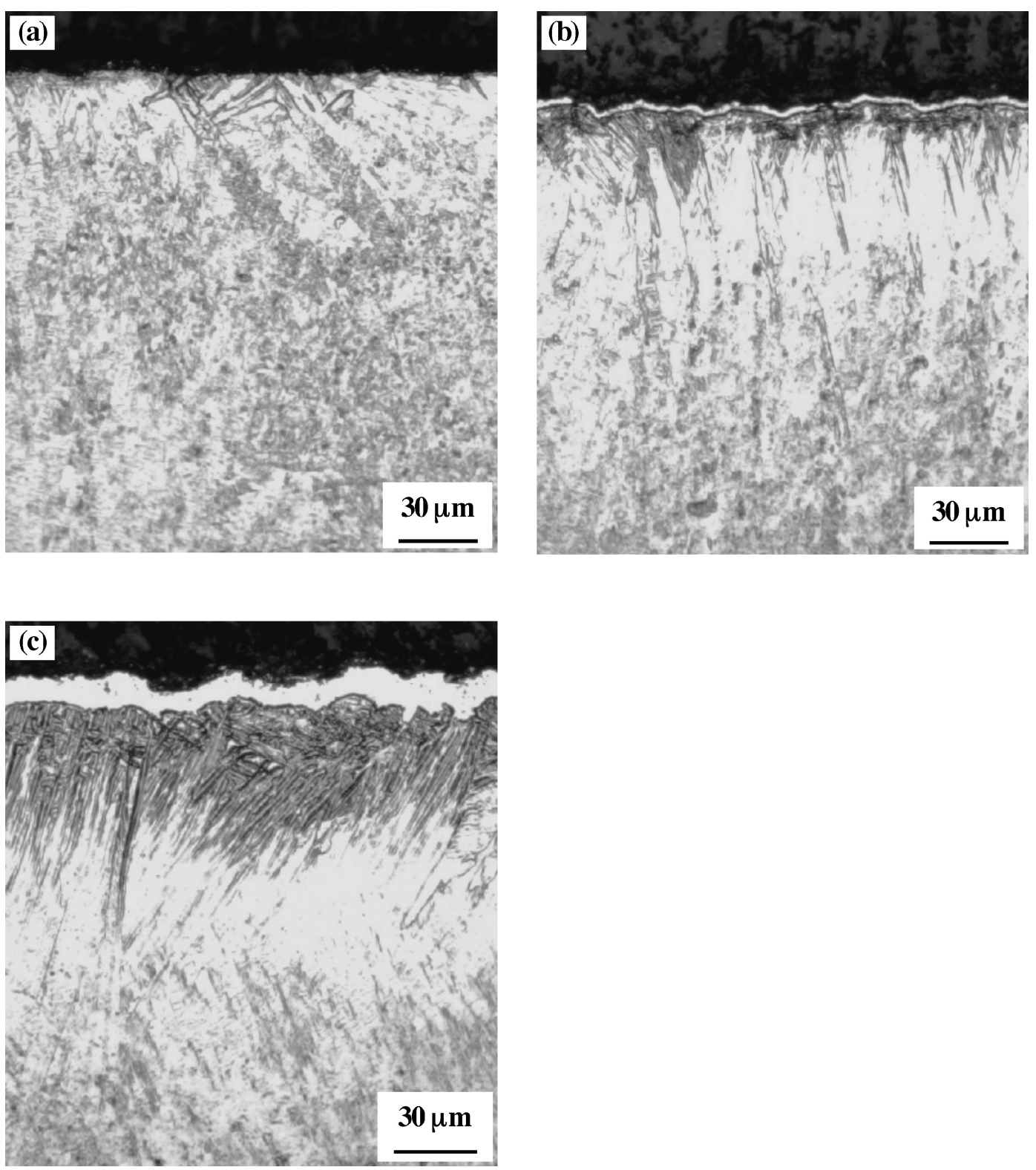

Fig. 12 Microstructures of cross section specimen after laser irradiation in an atmosphere of $\mathrm{Ar}: \mathrm{N}_{2}=30: 70(t=7)$ (a) $N=5$, (b) $N=20$ and (c) $N=40$.

$\mathrm{N}_{2}=30: 70$ を使用した場合の試料に対して，36 時間の摩耗 試験を行った場合の摩耗痕打よび $\mathrm{Ar}: \mathrm{N}_{2}=30: 70$ の場合の 摩耗相手材の $\mathrm{ZrO}_{2}$ ボールの表面状態を示す。シールドガス
に $\mathrm{Ar}=100 \%$ を使用した場合の試料抢よび母材の摩耗痕幅 を比較すると，母材の幅が約 $1.1 \mathrm{~mm}$ であるのに対して TiN 皮膜を形成しない $\mathrm{Ar}=100 \%$ の場合では $0.98 \mathrm{~mm}$ と同程度 
であった、シールドガスに $\mathrm{Ar}: \mathrm{N}_{2}=30: 70$ を使用した場合 では, 摩耗痕は約 $0.45 \mathrm{~mm}$ となり, 摩耗していない部分も 見られた。この摩耗していない部分は, 摩耗時間が 60 およ び $90 \mathrm{~h}$ でも認められた。 また，Fig. 14 (d)に示すように， 摩耗相手材である $\mathrm{ZrO}_{2}$ ボール表面には半径約 $0.45 \mathrm{~mm}$ の円 形状の摩耗痕が見られることから, Ar: $\mathrm{N}_{2}=30: 70$ の試料 と同程度の摩耗が $\mathrm{ZrO}_{2}$ ボールの表面で生じていると考えら れる.

Fig. 15 に比摩耗量と摩耗距離との関係を示す. 比摩耗量

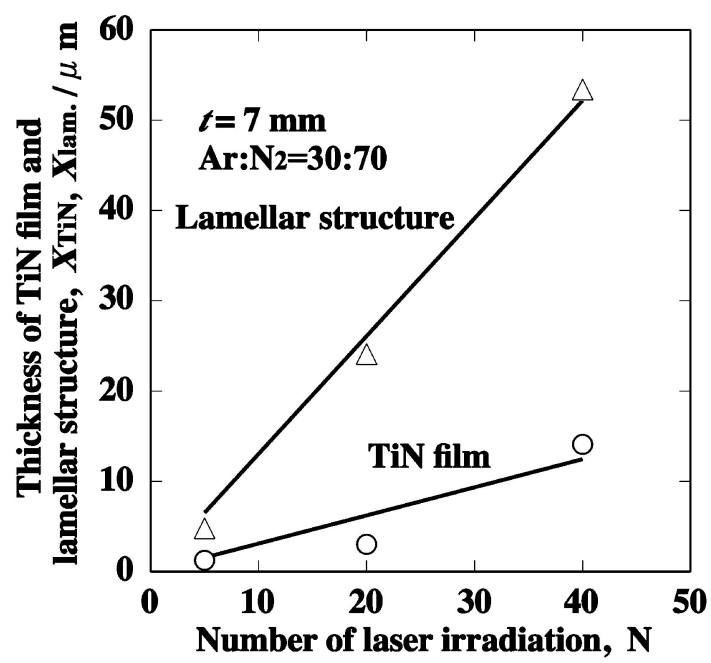

Fig. 13 Effect of number of laser irradiation on thickness of TiN film and lamellar structure $(t=7)$.
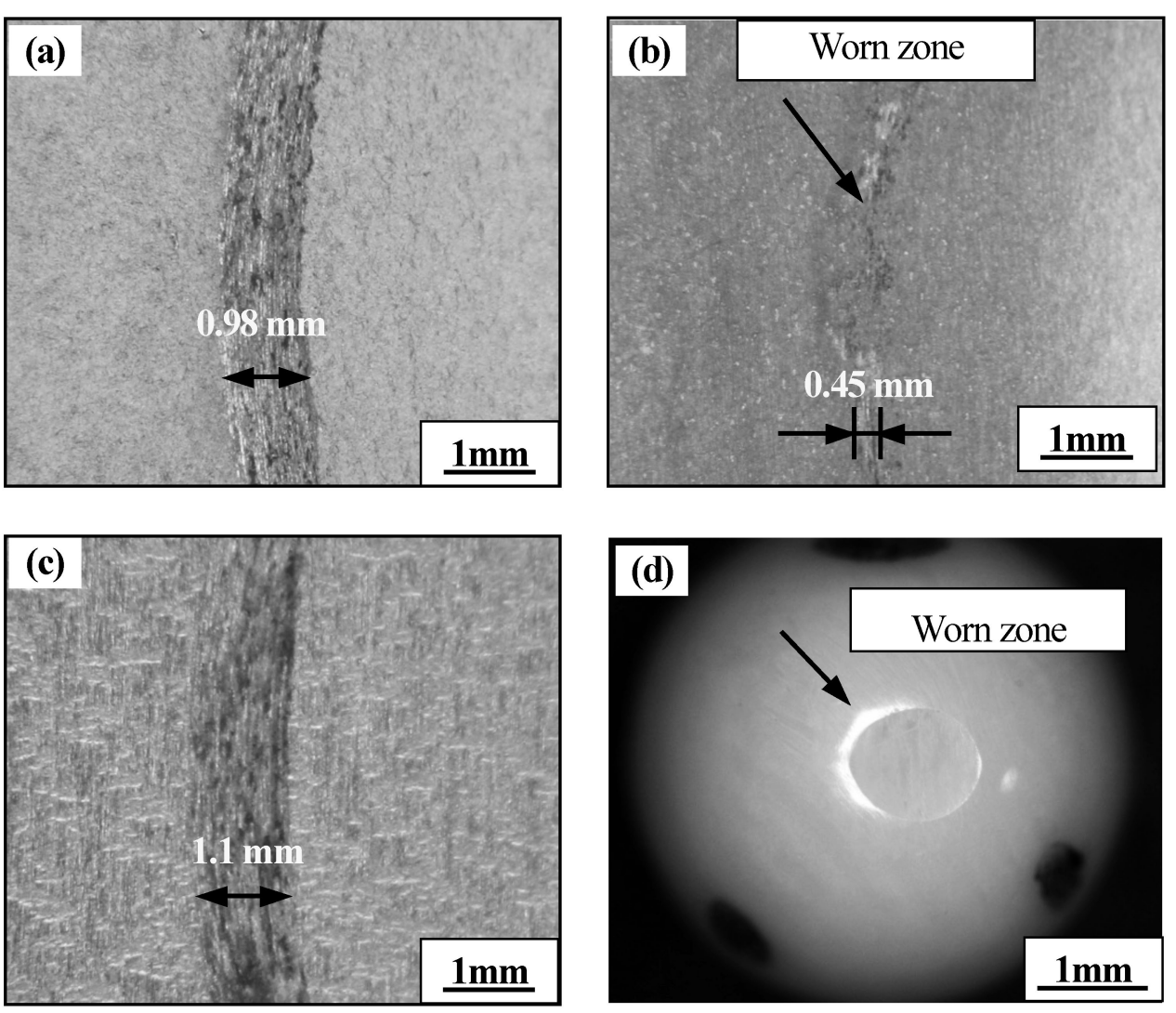

Fig. 14 Specimen surface and zirconia ball surface after abrasion tests of 36 hours (a) $\mathrm{Ar}=100 \%, N=40$, (b) $\mathrm{Ar}: \mathrm{N}_{2}=30: 70$, $N=40$, (c) base metal and (d) $\mathrm{ZrO}_{2}-\mathrm{Ball} \mathrm{Ar}: \mathrm{N}_{2}=30: 70, N=40(t=7)$. 
$10^{-8} \mathrm{~mm}^{3} \cdot(\mathrm{mm} \cdot \mathrm{N})^{-1}, \mathrm{Ar}=100 \%$ では約 $14.3 \times 10^{-8} \mathrm{~mm}^{3}$. $(\mathrm{mm} \cdot \mathrm{N})^{-1}$ のほぼ同程度な值を示している. $\mathrm{Ar}: \mathrm{N}_{2}=30$ : 70 でレーザ照射した場合では約 $0.75 \times 10^{-8} \mathrm{~mm}^{3} \cdot(\mathrm{mm}$. $\mathrm{N})^{-1}$ の比摩耗量を示し, 母材と比べると約 22 倍の耐摩耗性 の改善が認められた.

\section{4. 結 論}

工業用純チタン $\mathrm{TP} 340 \mathrm{C}$ および $\mathrm{TP} 270 \mathrm{H}$ に対してレーザ 照射による表面改質を行った結果をまとめると次のとおりで ある。

（1）窒素-アルゴン混合ガスおよび $\mathrm{N}_{2}=100 \%$ の䨌囲気内 においてレーザ照射したチタン表面には， TiN 皮膜および ラメラー組織が認められた。

（2） TiN 皮膜厚さは，窒素量が $70 \%$ で最大 $14 \mu \mathrm{m}$ が得ら れた

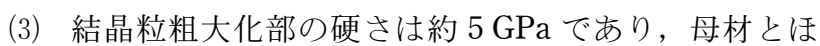
ぼ同程度の硬さであった。 TiN 皮膜硬さは表面近傍では約
$40 \mathrm{GPa}$ が得られ，母材の約 8 倍であった。ラメラー組織に おいて，窒素量の高い層および低い層の硬さはそれぞれ約 $10 \mathrm{GPa}$ および $6 \mathrm{GPa}$ であった.

(4) 60 時間の摩耗時間でのレーザ照射材の比摩耗量は約 $0.7 \times 10^{-8} \mathrm{~mm}^{3} \cdot(\mathrm{mm} \cdot \mathrm{N})^{-1}$ であり, これは母材の約 22 倍の 耐摩耗性を示す值であった。

\section{文献}

1) M. Niinomi: Electric Furnace Steel 73(2002) 113-120.

2) M. Oka: ZuSetsu Seikeigekashindanchiryoukouza, 15 Jinkoukansetsu·Baiomateriaru, (Medical View Co., Ltd., 1990) pp. 4-5.

3) T. Yamaguchi, K. Nishio, H. Era and M. Katoh: J. L. M. W. Const. 45 (2007) 561-568.

4) K. Nishio, T. Yamaguchi, H. Era and M. Katoh: Mater. Trans. 45 (2004) 1613-1619.

5) H. Takahashi, T. Morita, M. Shimizu and K. Kawasaki: Trans. J. Soc. Mech. Eng. Ser. A 59(1993) 2481-2486.

6) K. Maeda, T. Someya, B. Lee, J. Komotori and M. Shimizu: JSME Annual Meeting 2000, (2000) pp. 295-296.

7) http://www.tech.nite.go.jp/sbr/tr/tr00003.html 